\title{
The Effectiveness of E-Module on Buffer Solutions to Improve Students' Higher-Order Thinking Skills and Self-Regulated Learning
}

\author{
Alfiyani Lestari ${ }^{*}$ and Sri Atun ${ }^{1}$ \\ ${ }^{1}$ Department of Chemistry Education, Faculty of Mathematics and Natural Science, \\ Yogyakarta State University, Colombo Street No.1, Karangmalang, Yogyakarta, 55281, \\ Indonesia \\ *E-mail: alfiyanilestari.2019@students.uny.ac.id
}

Received: 24 September 2021; Accepted: 16 November 2021; Published: 31 December 2021

\begin{abstract}
This study aims to determine the difference between Higher Order Thinking Skills (HOTS) and Students Self Regulated Learning (SRL) before and after using e-module based on the 7E (elicit, engage, explore, explain, elaborate, evaluate, and extend) learning cycle on the buffer solution material, and to determine the percentage of its effectiveness. The research use a quasi experiment with one-group pretest-posttest design. The subjects of this research were students of natural science $11^{\text {th }}$ grade in one of senior high schools in Yogyakarta. The instrument used were test in the form of HOTS pretest-posttest description question and nontest in the form of self-regulated learning questionnaire. The data analysis technique used is Hotteling's $T^{2}$ test. The results showed that the significance value was $0.000<=0.05$, then $\mathrm{H}_{0}$ was rejected. There were differences in students' HOTS and SRL before and after using e-module based on the 7E learning cycle. The effectiveness of using e-module show by HOTS and SRL simultaneously (36.8\%), HOTS (25.2\%), and SRL (20.5\%).
\end{abstract}

Keywords: buffer solution, e-module, HOTS, learning cycle 7E, self-regulated learning

DOI: https://doi.org/10.15575/jtk.v6i2.13772

\section{Introduction}

Nowadays, we are facing a problem with the emergence of Covid-19. The disease emerges in Wuhan, China, and surprisingly spreads rapidly to China and the whole world (Wickramasinghe et al., 2020). The dissemination of coronavirus disease has arrived in Indonesia and influenced many sectors, especially education. The government in every country must decide to close schools to cut the live chain of Covid-19 (Aji, 2020). As a result, the teaching-learning process that usually occurs in school now must be done at home. The result of research by Sintema (2020) revealed that Covid-19 has a bad influence on the education sector. One of the influence was deficient in e-learning facilitation used to interact with teachers and students.

Nowadays, teachers are demanded to create a new learning strategy using technology in the teaching-learning process in which it can be applied in pandemic condition through online/ long distance learning (Saraswati et al., 2019). The use of technology in the teachinglearning process can be applied through a technology-based teaching media (Açişli et al., 2011; Warburton, 2003). Teaching media is an education's scaffolding that can be used in the teaching-learning process to increase the effectiveness and the efficiency in reaching the aim of the teaching-learning process (Sanaky, 2013). A technology that is suitably used in the Covid-19 pandemic is the electronic module 
(e-module). An e-module is a printed medium changed into a new module used technology (Voithofer, 2005).

Learning media can be collaborated with learning models to obtain more optimal results (Istuningsih et al., 2018). Especially now that Indonesian education refers to the 2013 curriculum, which demands learner-centered learning through a scientific approach (Kemendikbud, 2018). One model can be applied in the learning process with a scientific approach is the 7E learning cycle model (Sornsakda et al., 2009). The 7E learning cycle model uses constructivism theory which requires students to be active during the learning process (Balta \& Sarac, 2016).

Many researchers have studied the learning cycle 7E model and have shown that learning using the learning cycle can improve students' critical thinking skills, conceptual understanding, and learning outcomes (Hardiansyah et al., 2013; Balta \& Sarac, 2016). However, because the learning cycle 7E model takes a long time, many schools continue to use conventional teacher-centered methods in the learning process (Istuningsih et al., 2018). As a result, student learning activities decrease and impact the common understanding of basic concepts and student learning outcomes (Istuningsih et al., 2018).

Education nowadays enters the globalization era in the $21^{\text {st }}$-century and is faced with more complex challenges toward the education system in the world. According to UNESCO (2009), many skills that must be mastered in $21^{\text {st }}$-century, there are creativity and innovation, critical thinking and problem solving, communication and collaboration. An effort that must be made to run education challenges in $21^{\text {st }}$-century is a HOTS (Sahin et al., 2014).

Brookhart (2010) explained the HOTS in three categorizations, there are (1) Higher order thinking as a knowledge transfer; (2) Higher order thinking as the ability to have the critical thinking; and (3) Higher order thinking as an ability to solve problem. HOTS is a skill to have a high-order thinking level that relates to understanding students' fundamental concepts (Tacoshi \& Fernandez, 2014). However, some research defines that weak mastering of the fundamental concept still becomes a general problem for chemistry students (Cooper et al., 2010; Burrows \& Mooring, 2015). The weakness toward mastering the chemistry concept will make students less motivated to learn the next chemistry topic (Celikten et al., 2012).

The development of HOTS in the teaching and learning process refers to the 2013 curriculum which is an improvement from the previous curriculum. According to Bloom's taxonomy (1956), HOTS is higher-order thinking based on the newest revision model (Othman et al., 2015; Anderson \& Krathwohl, 2001). Therefore, chemistry teachers should strengthen their fundamental ability and develop HOTS of students in the teachinglearning process at school in the framework of developing students' skills at solving chemistry HOTS problems based (Harta et al., 2020). On the contrary, it may be difficult because some chemistry teachers still lack the knowledge to stimulate students' HOTS (Fernandez et al., 2013; Azraai \& Talib, 2015). Thus, the students' analysis skill in solving chemistry task-based higher-order thinking category is still weak (Harta et al., 2020).

Students commonly use HOTS to control knowledge, focus on responsibility, and to have a SRL (Paris \& Paris, 2001; Brookhart, 2010). Hendrian et al. (2017) defined SRL and habitual learning are essential factors influencing HOTS. Experts of education agree that SRL is the most important factor in academic motivation and academic achievement (Zumbrunn et al., 2011). Hence, the fact-based on Zimmerman (1990) explained that the SRL of students still shows less with the low of academic achievement. Students with good SRL can set their learning style, initiative to search for information, search for solve barriers, and be more responsible (Zimmerman, 1990). Because of that, if students can solve higher-order thinking skill tasks, thus it can be said that they have a good SRL. 
Complex material comes with many concepts, calculations, and applications in daily life. Hence, the buffer solution is perceivable at a lower cognitive level and needs analysis, evaluation, and creativity to master the concepts (Hardinita \& Muchlis, 2015). Students that want to understand buffer solutions should master macroscopic, microscopic, and symbolic (Maratusholihah et al., 2017). The concept which becomes pre-conditions study of buffer solution is chemical equilibrium and acid/base concept (Bilgin \& Geban, 2006). The result of Orgill and Sutherland (2008) research, show that students find it difficult to relate to the concept of buffer solution as follow, students tend to focus on macroscopic; students can identify that buffer belongs to either acid or base but they cannot relate the relationship between acid and base conjugation; and students find difficult to determine factors that are influence the buffer capacity.

The aims of this research are to know the difference and effectiveness of HOTS and SRL of students independently before and after using an e-module based on the learningcycle 7E in buffer solution concept at senior high school.

\section{Research Method}

\subsection{Research Design}

The methode used in the research is quasi experiment with one-group pretest-posttest design. This research was conducted from March to April 2021. Research data was collected by conducting an online/distance learning process. The research design can be seen in Figure 1 and Table 1.

\subsection{Sampling}

The sample of this study amounted to 70 students from the $11^{\text {th }}$ grade of Natural Sciences in one of the high schools in Yogyakarta. The sampling technique of this research is simple random sampling. The random sampling is a technique of randomly selecting samples from a specified population which each member of the population has an equal probability of being chosen. It is also meant to be an unbiased representation of a group of population. Before using questionnaires, empirical validation was carried out with the number of respondents for the HOTS questions pretest as many as 102 students and posttest as many as 124 students. While the empirical test for the SRL questionnaire amounted to 66 students.

\subsection{Techniques and Instruments}

Data collection techniques used in the form of test and non-test techniques. The test technique is in the form of questions of HOTS, which include pretest and posttest, while the non-test technique is in the form of a SRL questionnaire for students.

HOTS questions are arranged based on cognitive levels C4-C6, analyzing; evaluating; and creating five questions for the pretest and the posttest. Meanwhile, this SRL Instrument was prepared by adapting and developing from Zimmerman (1989) and Wolters et al. (2009). The number of statements in the SRL questionnaire is 24 using a four point likert scale.

\subsection{Data Analysis Technique}

\subsubsection{Validity and Reliability Test}

All of the instruments made must be through validation test and rehabilitation before being used in the research. The validation tests validation theory and empiric.

The validation theory done by expert judgement toward the set teaching equipment, HOTS questions, and questionnaire of SRL. The result of the validation theory is qualitative data such as suggestions or advice toward HOTS questions and SRL questionnaire. The suggestion given by expert judgement taken as a foundation to repair the teaching equipment, the HOTS questions and the questionnaire of SRL of students. The validation theory is used to set the products that will be developed have had good content or not (Aiken, 1999).

After revision has been done, the next step is empirical validation with a trial HOTS questions and questionnaire of students' SRL besides the research samples. Empirical tests 
toward HOTS questions are pretest and posttest questions with 120 test respondents of students and posttest with 124 students. Hence, the empirical test toward questionnaire of SRL is 66 students. The empirical test results were done using the Rasch model's Quest program.

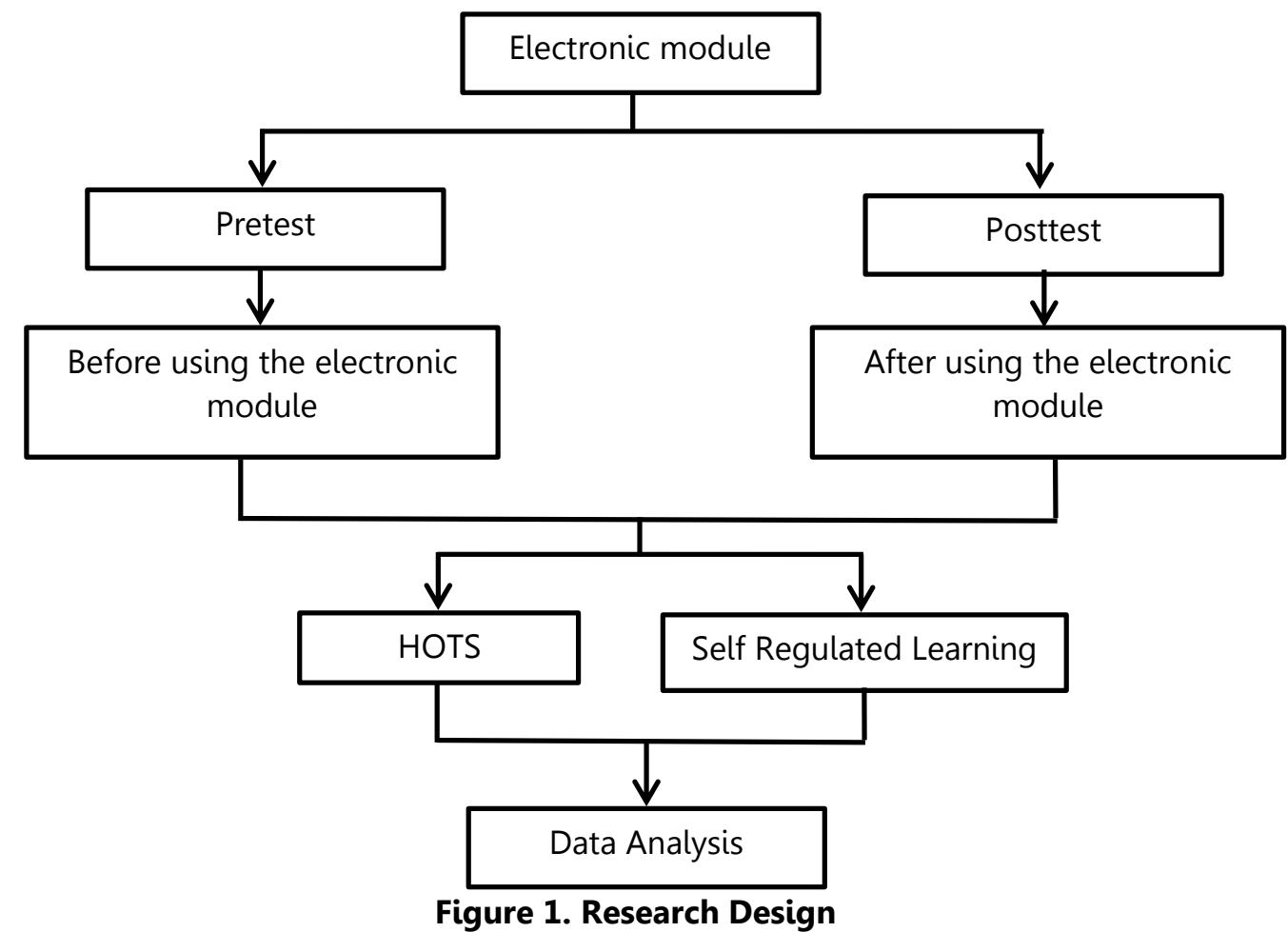

Table 1. One-Group Pretest-Posttest Design

\begin{tabular}{ccc}
\hline Pretest & Treatment & Posttest \\
\hline $\mathrm{O}_{1}, \mathrm{P}_{1}$ & $\mathrm{X}$ & $\mathrm{O}_{2}, \mathrm{P}_{2}$ \\
\hline
\end{tabular}

$* \mathrm{O}_{1}=$ Pretest HOTS; $\mathrm{O}_{2}=$ Posttest HOTS; $\mathrm{P}_{1}=$ SRL Questionnaire (Pretest); $\mathrm{P}_{2}=$ SRL Questionnaire (Posttest); and $\mathrm{X}=$ Treatment.

Reliability is a coefficient that shows the level of consistency of the measurement results of a test. The estimation of the reliability of the questions according to the IRT (Item Response Theory) analysis can be known based on the item separation index (item estimate) and person separation index (case estimate). The criteria for item estimate and case estimate values can be seen in Table 2 (Smith, 2005).

Table 2. Criteria for Item Estimate and Case Estimate

\begin{tabular}{ccc}
\hline No & Value & Category \\
\hline 1 & $<0.67$ & Deficient \\
2 & $0.67-0.80$ & Average \\
3 & $0.81-0.90$ & Good \\
4 & $0.91-0.94$ & Very Good \\
5 & $>0.94$ & Excellent \\
\hline
\end{tabular}

\subsubsection{Research Data Analysis}

The data analysis technique used in Hotelling's $\mathrm{T}^{2}$ test was carried out with the help of SPSS 16.0. The analysis can be done to meet the need of nine pre-qualification assumption tests of MANOVA, which are (1) the independent variable consists of two or more independent groups; (2) The dependent variable must be measured at the interval or ratio level; (3) there is no relationship between 
observers within each group or between groups; (4) an adequate sample size of at least 25; (5) no univariate or multivariate outliers; (6) there is multivariate normality; (7) there is a linear relationship between each pair of dependent variables for each independent variable; (8) there is homogeneity can be seen from the Box's $M$ test; and (9) there is no multicollinearity by looking at the Tolerance and VIF values, if the Tolerance value $>0.10$ and VIF < 10, then the data is free from multicollinearity symptoms.

\subsubsection{Multivariate Test}

Multivariate test is Hotelling's $\mathrm{T}^{2}$ test. Hotelling's $T^{2}$ test was used to analyze the difference between HOTS and SRL before and after using the e-module with learning cycle 7E.

\subsubsection{Univariate Test}

Univariate test is a between-subject effect test used to know every difference of HOTS and SRL of students before and after using an emodule on the learning cycle $7 \mathrm{E}$ in buffer solution concept.

Thus, the effectivity contribution percentage of e-module on the learning cycle 7E toward HOTS and SRL can be done by the help of SPSS with searching for the partial eta squared and multiple it by $100 \%$.

\section{Result and Discussion}

The research using Google Meet, Whatsapp Group, and Google Form at SMAN 7 Yogyakarta. Google Meet is used when the teaching-learning process and Whatsapp Group are done to give information related to the teaching-learning process. Hence, Google Form was used to take the pretest and posttest data with supervision through Google Meet. The data taken by the research is quantitative of HOTS and SRL of students' scores. The test aims to know the differences between HOTS and SRL of students simultaneously and independently before and after use the emodule on the learning cycle $7 \mathrm{E}$ in buffer solution concept and to know the effectivity contribution given.

\subsection{Validity and Reliability Test}

All of the instruments, either HOTS questions (pretest and posttest) or SRL questionnaires, were done. The empirical test involved 102 students toward pretest, 124 students toward posttest, and 66 students toward SRL questionnaire. The result of the empirical test was then counted in the Quest program to know the validity and reliability of every question. The question is valid when infit MNSQ and outfit MNSQ in every question reveals appropriate Partial Credit Model. The questions are valid when the value is between infit MNSQ 0.77 until 1.33 and the outfit MNSQ between 0.5 until 1.5 (Adam \& Khoo, 1996; Boone et al., 2014). The empirical test result for SRL can be seen in Table 3.

Table 3 show that HOTS questions for pretest and posttest are infit MNSQ area with the value of 0.77 until 1.33 and the outfit MNSQ in the value of 0.5 until 1.5 . So, it can be concluded that pretest questions consisting of five questions and posttest consisting of six questions are valid, and all questions can be used in collecting research data. The empirical test results for the students' SRL questionnaire can be seen in Table 4.

Table 3. Infit MNSQ and Outfit MNSQ Value on the Pretest and Posttest Items

\begin{tabular}{ccccc}
$\begin{array}{c}\text { Test } \\
\text { Number }\end{array}$ & $\begin{array}{c}\text { Infit MNSQ } \\
\text { HOTS Pretest }\end{array}$ & Outfit MNSQ & \multicolumn{2}{c}{ HOTS Posttest } \\
Infit MNSQ & Outfit MNSQ \\
\hline 1 & 0.90 & 0.87 & 0.99 & 0.84 \\
2 & 1.10 & 1.33 & 0.86 & 0.87 \\
3 & 0.81 & 0.90 & 1.01 & 1.43 \\
4 & 1.01 & 1.02 & 0.86 & 0.89 \\
5 & 0.80 & 1.33 & 1.14 & 1.29 \\
6 & & & 0.90 & 1.19 \\
\hline
\end{tabular}


Table 4 show that the data of fit item in point 24 of SRL questionnaire revealed that all of the questions is valid because it is in range of infit MNSQ of 0.77 until 1.33. Reability value of every question in output Quest can be seen in estimation item and estimation case. A question is reliable when a test produces a consistent result repetitively with the same subjects and conditions. The result of the reability test can be seen in Table 5 .

Table 4. MNSQ Infit and MNSQ Outfit Values on SRL Items

\begin{tabular}{lccc}
\hline \multicolumn{1}{c}{ Indicator } & Item & SRL & Outfit MNSQ \\
\hline Rehearsal Strategies & Number & Infit MNSQ & 1.19 \\
& 1 & 1.10 & 1.14 \\
Elaboration Strategies & 2 & 1.11 & 1.11 \\
& 3 & 1.09 & 0.93 \\
Metacognitive Self-Regulation & 4 & 1.92 & 1.01 \\
& 5 & 0.97 & 0.96 \\
Mastery self-talk & 6 & 0.94 & 0.82 \\
Relevance Enhancement & 7 & 0.88 & 1.05 \\
Performance/relative ability self-talk & 8 & 1.02 & 0.99 \\
Environmental & 9 & 1.01 & 0.87 \\
Self-Consequating & 10 & 0.90 & 1.12 \\
Effort Regulation & 11 & 1.10 & 1.13 \\
& 12 & 1.10 & 1.17 \\
Regulating Time and Study Environment & 13 & 1.0 & 0.90 \\
& 14 & 0.94 & 0.106 \\
General Intention to Seek Needed Help & 15 & 0.98 & 0.92 \\
\hline
\end{tabular}

Table 5 show the coefficient summary of case estimates to HOTS Pretest Question and Posttest are 0.77; hence, the SRL questionnaire is 0.72. According to Gliem and Gliem (2003), the three coefficient values of capability summary of case estimates are acceptable.
Hence, the coefficient value of capability of summary estimates in HOTS pretest questions and SRL questionnaire are 0.79 and 0.82 belong to acceptable categorization. In the capability questions HOTS posttest is 0.82 belongs to good categorization.

Table 5. Reability Value

\begin{tabular}{lcc}
\multicolumn{1}{c}{ Kind of Question } & \multicolumn{2}{c}{ Reability Coefficient } \\
& Summary of Item Estimates & Summary of Case Estimates \\
\hline HOTS Pretest Questions & 0.79 & 0.70 \\
HOTS Posttest Questions & 0.82 & 0.70 \\
SRL Questionnaire & 0.74 & 0.72 \\
\hline
\end{tabular}

All of the instruments that have been validated can be directly used in the learning process. The research was conducted in one of the senior high schools in Yogyakarta, the $11^{\text {th }}$ grade of natural sciences; students began with taking pretest HOTS questions and filling out SRL questionnaires. It was done to know the capability of students before doing any actions. Hence, the other process was teaching-learning process using e-module based on the learning cycle 7E and end by final learning with posttest of HOTS question and filling SRL questionnaire. The average of pretest and posttest can be seen in Table 6 . 
Effectiveness Using E-Module Based on the Learning Cycle $7 E$ to Increase HOTS and Students Self-Regulated Learning

The result of Table 6 revealed that the HOTS and SRL after posttest was higher than before the pretest using an e-module of learning cycle based 7 . It can be seen in the mean or the average score. Thus, it can be concluded that students that learn with e-module based on the learning cycle $7 \mathrm{E}$ got better achievement than before the use of e-module of learning cycle 7E based.

Table 6. The Average Result of Pretest - Posttest HOTS questions and Students' SRL Questionnaire

\begin{tabular}{clccc}
\hline Variabel & Treatment & Mean & Lowest Score & Higher Score \\
\hline \multirow{2}{*}{ HOTS } & Pretest & 59.07 & 34 & 89 \\
& Posttest & 79.80 & 50 & 100 \\
\multirow{2}{*}{ SRL } & Pretest & 78.95 & 63 & 97 \\
& Posttest & 86.07 & 68 & 101 \\
\hline
\end{tabular}

The differences between the two variables toward the action can be made by using the Hotelling $T^{2}$ Test with the help of MANOVA analysis, so it must meet the need of nine prequalifications assumptions of MANOVA.

Table 7. The Result Multivariate Normality Test

\begin{tabular}{lcc}
\hline Variabel & Treatment & $\begin{array}{c}\text { Shapiro- } \\
\text { Wilk } \\
\text { Sig. }\end{array}$ \\
\hline \multirow{2}{*}{ HOTS } & Pretest & 0.139 \\
& Posttest & 0.56 \\
SRL & Pretest & 0.843 \\
& Posttest & 0.151 \\
\hline
\end{tabular}

The research has met the nine prequalifications of MANOVA, (1) There are two tied variables which are HOTS and SRL; (2) There are two free variables teaching-learning before and after using an e-module based on the learning cycle 7E measured with giving pretest and posttest; (3) There is no relation between the samples; (4) The samples were more than 25 that is 70 students; (5) There was neither outlier univariate nor multivariate; (6) Which were normally distributed multivariate. Normality test using Shapiro-Wilk Test of
Normality with SPSS. The results of the normality test can be seen in Table 7 .

The normality test results in Table 7 show that all sig values $>0.05$, then $\mathrm{H}_{0}$ is accepted. So it can be concluded that all data comes from a normally distributed population; (7)There are linear relations in every tied pair variable to every free variable; (8) Homogeneity can be seen from the value of Box's Test of Equality of Covariance Matrices (Box's M) can be seen in Table 8.

Table 8. The Results Homogeneity Test

\begin{tabular}{cc}
\hline Box's $\mathbf{M}$ & $\mathbf{2 , 3 5 4}$ \\
\hline $\mathrm{F}$ & 0.772 \\
df1 & 3 \\
df2 & $3.428 \mathrm{E} 6$ \\
Sig. & 0.509 \\
\hline
\end{tabular}

Table 8 shows that the Box's $M$ value is 2,354 with a significance value of two-tailed sig. $0.509>0.05$, then $\mathrm{H}_{0}$ is accepted. So it can be concluded that the covariance variance matrix is homogeneous; (9) No multi-collinearity was shown by looking at the Tolerance and VIF values, as shown in Table 9. Table 9 shows the results of the multicollinearity test.

Table 9. The Result Multicollinearity Test

\begin{tabular}{|c|c|c|c|c|c|c|c|}
\hline \multirow{2}{*}{ Model } & \multicolumn{2}{|c|}{$\begin{array}{c}\text { Unstandardized } \\
\text { Coefficients }\end{array}$} & \multirow{2}{*}{$\begin{array}{c}\begin{array}{c}\text { Standardized } \\
\text { Coefficients }\end{array} \\
\text { Beta } \\
\end{array}$} & \multirow{2}{*}{$\mathbf{t}$} & \multirow{2}{*}{ Sig. } & \multicolumn{2}{|c|}{$\begin{array}{l}\text { Collinearity } \\
\text { Statistics }\end{array}$} \\
\hline & B & $\begin{array}{l}\text { Std. } \\
\text { Error }\end{array}$ & & & & Tolerance & VIF \\
\hline (Constant) & -1.318 & 0.366 & - & 3.602 & 0.00 & & \\
\hline $\begin{array}{l}\text { SRL } \\
\text { HOTS }\end{array}$ & $\begin{array}{l}0.022 \\
0.014\end{array}$ & $\begin{array}{l}0.004 \\
0.002\end{array}$ & $\begin{array}{l}0.351 \\
0.416\end{array}$ & $\begin{array}{l}5.011 \\
5.935\end{array}$ & $\begin{array}{l}0.00 \\
0.00\end{array}$ & $\begin{array}{l}0.940 \\
0.940\end{array}$ & $\begin{array}{l}1.064 \\
1.064\end{array}$ \\
\hline
\end{tabular}


Effectiveness Using E-Module Based on the Learning Cycle $7 E$ to Increase HOTS and Students Self-Regulated Learning

If the tolerance value $>0.10$ and $\mathrm{VIF}<10$, the data is free from multicollinearity symptoms. The results of the multicollinearity test on the research data are the Tolerance value $=0.940$ and the VIF value $=1.064$. So it can be concluded that the data is free from multicollinearity symptoms at $0.940>0.10$ and $1.064<10$. The nine pre-qualifications of MANOVA have been fulfilled than in the other process can be analyzed with the use of MANOVA to prove the research hypotheses.

\subsubsection{Multivariate test}

Multivariate test was used to know the differences in HOTS and SRL before and after using the e-module based on the learning cycle 7E. The multivariate test can be seen in a multivariate test of Hotelling's test Trace in Table 10.

Table 10. The Result of Multivariate Test

\begin{tabular}{ccccc}
\hline Test & F & Sig. & Result & Partial Eta Squared \\
\hline Hotelling's Trace & $39.846 \mathrm{a}$ & 0.000 & $\mathrm{H}_{0}$ declined & 0.368 \\
\hline
\end{tabular}

Table 10 show the result of the multivariate test. The decision was taken by comparing the multivariate test with the multivariate criterion test. The decision was taken using $\alpha=0.05$ if the value of Hotelling's Trace sig. $<\alpha$ then $\mathrm{H}_{0}$ is declined, and $\mathrm{H}_{\mathrm{a}}$ accepted. It can be concluded that both tied variables were different with specific actions. Based on the analyses results of the multivariate test in Table 10, Hotteling's Trace sig. $0.000<0.005$, so $\mathrm{H}_{0}$ was declined, and $\mathrm{H}_{\mathrm{a}}$ was accepted. Thus, it can be concluded that there were differences in HOTS and SRL before and after the use of e-module based on the learning cycle 7E.

The result of the research is in line with the Istuningsih et al. (2018) research based on the result of pretest and post-test that showed the use of a scientific approach with the use of an e-module of learning cycle $7 \mathrm{E}$ based is effectively used in teaching-learning process. In Table 10, Partial Eta Squared revealed how much the influence of media that is developed toward the tied variable. The percentage toward the influence of the e-module in the teaching process toward HOTS can be known by multiplying it with $100 \%$ of the score in partial eta squared. The result of partial eta squared is $0.368 \times 100 \%=36.8 \%$, it means the effectivity contribution percentage of emodule based on the learning cycle 7E toward HOTS and SRL was $36.8 \%$.

\subsubsection{Univariate Test}

The next MANOVA test is the Univariate Test (Intermediate Test - Subject Effect). The test was conducted to determine the differences in students' HOTS before and after using the emodule on the buffer solution concept. However, the test is also used to determine the differences in students' SRL before and after using the module based on the 7E learning cycle in the concept of a buffer solution as well. The results of the Between-Subject Effect Test can be seen in Table 11.

Table 11. The Result of Test of Between-Subject Effect

\begin{tabular}{ccc}
\hline Tied Variable & Sig. & Partial Eta Squared \\
\hline HOTS & 0.000 & 0.252 \\
SRL & 0.000 & 0.205 \\
\hline
\end{tabular}

The test of Between - Subject Effect with decision criterion used if the signification $<\alpha$ $=0.05$ thus $\mathrm{H}_{0}$ is declined and if the sig. is > 0.05 so the $\mathrm{H}_{0}$ is accepted (Pallant, 2007). Table 11 show the significant score of HOTS is 0.000 with the partial eta squared 0.252 , which meant $\mathrm{H}_{0}$ was declined so there are differences in students' HOTS before and after the use of e-module based on the learning cycle $7 E$ in buffer solution concept.

Salbiah et al. (2015) said that HOTS are involved critical thinking, creativity, logic, reflectivity, skill to solve the problem, and metacognition. Budiarti et al. (2016) found that the using of e-module helps increase the students' critical thinking. The result is in line 
with the research of Sauki and Talib (2020) that with the use of Polysa method, 5E and 7E can answer the questions of HOTS and it can increase students' learning achievement.

The research result of Kusumawardani et al. (2019) show that learning process using learning cycle 7E model had proven can increase students' learning achievement than the students taught using $5 \mathrm{E}$ learning cycle. The practical contribution percentage of an emodule toward HOTS was $25.2 \%$. The test score of between-subject effect sig. $0.000<$ 0.05 thus, $\mathrm{H}_{0}$ was declined, and can be concluded that there were differences SRL of students before and after the use of e-module based on the learning cycle 7E with the number contribution of $20.5 \%$ seen from the score of partial eta square. The finding result is in line with the research of Khoiriah et al. (2019) showed that the application of instrument scoring of the effective HOTS can develop the SRL of students. It was in line with the Brookhart's statement (2010) that said students' who have good habitual action of HOTS and SRL.

\section{Conclusion}

There is the difference between HOTS and SRL of students simultaneously before and after the use of e-module based on the learning cycle 7E in buffer solution concept. The effectiveness contribution of HOTS and SRL of students simultaneously was $36.8 \%$, for HOTS was $25.2 \%$, and for the SRL was $20.5 \%$.

This research has important implications for chemistry education, which are syllabus and chemistry teachers can use lesson plans as guidelines for implementing learning with the learning cycle 7E model assisted by e-module or other media; Pretest and posttest questions of HOTS can be used to assess students' learning achievement so that they can practice working on questions with a high cognitive level.

Some further recommendations that can be considered for further research are developing and implementing an e-module based on the learning cycle 7E on other chemistry concept.
In addition, other research can be done by comparing the use of e-modules based on the $7 E$ learning cycle with similar studies based on the $9 \mathrm{E}$ learning cycle.

\section{References}

Açişli, S., Yalçin, S. A., \& Turgut, Ü. (2011). Effects of the $5 \mathrm{E}$ learning model on students' academic achievements in movement and force issues. Procedia Social and Behavioral Sciences, 15, 2459-2462. https://doi.org/10.1016/j.sbspro.2011.0 4.128

Adam, R. J., \& Khoo, S. (1996). Acer quest version 2.1. Camberwell, Victoria: The Australian Council for Educational Research.

Aiken, L. R. (1999). Personality assessment: methods and practices. Toronto: Hogrefe \& Huber Publishers.

Aji, R. H. S. (2020). Dampak covid-19 pada pendidikan di Indonesia: sekolah, keterampilan, dan proses pembelajaran. Jurnal Sosial \& Budaya Syar-I, 7(5), 395402.

https://doi.org/10.15408/sjsbs.v7i5.153 14

Anderson, L. W., \& Krathwohl, D. R. (2001). A taxonomy for learning, teaching, and assessing; a revision of Bloom's taxonomy of educational objectives. New York: Addison Wesley Longman.

Azraai, O., \& Talib, O. (2015). Tahap kefahaman asas kimia organik pelajar kolej matrikulasi aliran teknikal. Jurnal Pendidikan Sains \& Matematik Malaysia, 5(2), 86-97. Retrieved from https://ejournal.upsi.edu.my/index.php/ JPSMM/article/view/2153

Balta, N., \& Sarac, H. (2016). The effect of 7E learning cycle on learning in science teaching: a meta-analysis study. European Journal of Educational 
Research, $5(2)$,

$61-72$. https://doi.org/10.12973/eu-jer.5.2.6

Bilgin, I., \& Geban, O. (2006). The Effect of cooperative learning approach based on conceptual change condition on students' understanding of chemical equilibrium concepts. Journal of Science Education and Technology, 15(1), 31-46. https://doi.org/10.1007/s10956-0060354-z

Bloom, B. S. (1956). Taxonomy of educational objectives. Vol. 1: Cognitive domain. New York: McKay.

Boone, W. J., Staver, J. R., \& Yale, M. S. (2014). Fit. In Rasch analysis in the human sciences, 159-189. Springer, Dordrecht. https://doi.org/10.1007/978-94-0076857-4_8

Brookhart, S. M. (2010). How to assess higher order thinking skills in your classroom. United States of America: ASCD Member Book.

Budiarti, F., Nuswowati, M., \& Cahyono, E. (2016). Guided inquiry berbantuan eModul untuk meningkatkan keterampilan berpikir kritis. Journal of Innovative Science Education, 5(2), 144151. Retrieved from https://journal.unnes.ac.id/sju/index.ph p/jise/article/view/14264/7795

Burrows, N. L., \& Mooring, S. R. (2015). Using concept mapping to uncover students' knowledge structures of chemical bonding concepts. Chemistry Education Research and Practice, 16(1), 53-66. https://doi.org/10.1039/C4RP00180J

Celikten, O., Ipekcioglu, S., Ertepinar, H., \& Geban, O. (2012). The Effect of the Conceptual Change Oriented Instruction through Cooperative Learning on $4^{\text {th }}$ Grade Students' Understanding of Earth and Sky Concepts. Science Education International, 23(1), 84-96. Retrieved from https://eric.ed.gov/?id=EJ975551
Cooper, M. M., Grove, N., Underwood, S. M., \& Klymkowsky, M. W. (2010). Lost in Lewis structures: an investigation of student difficulties in developing representational competence. Journal of Chemical Education, 87(8), 869-874. https://doi.org/10.1021/ed900004y

Fernandez, C., Holbrook, J., Mamlok-Naaman, R., \& Coll, R. K. (2013). How to teach science in emerging and developing environments. In Teaching Chemistry-A Studybook: SensePublishers.

Gliem, J. A., \& Gliem, R. R. (2003). Calculating, interpreting, and reporting Cronbach's alpha reliability coefficient for Likerttype scales. [Conference presentation]. Midwest Research-to-Practice Conference in Adult, Continuing, and Community Education, Columbus, Ohio : Ohio State University. https://scholarworks.iupui.edu/handle/1 805/344

Hardiansyah, D., Rusnayati, H., \& Waslaluddin. (2013). Penerapan model pembelajaran learning cycle 7E untuk meningkatkan keterampilan berpikir kritis dan penguasaan konsep siswa SMA. Jurnal Pengajaran Fisika Sekolah Menengah, 5(1), 28-33. Retrieved from https://www.researchgate.net/publicati on/298323380_Penerapan_Model_Pemb elajaran_Learning_Cycle_7E_untuk_Meni ngkatkan_Keterampilan_Berpikir_Kritis_ dan_Penguasaan_Konsep_Siswa_SMA

Hardinita, E., \& Muchlis. (2015). Penerapan model pembelajaran pembelajaran cycle 7E untuk meningkatkan keterampilan berpikir kritis siswa pada materi pokok larutan penyangga kelas XI MIA SMA negeri 1 Puri Mojokerto. UNESA Journal of Chemical Education, 4(3), 486-494. Retrieved from https://jurnalmahasiswa.unesa.ac.id/ind ex.php/journal-of-chemicaleducation/article/view/13284/12194 
Harta, J., Rasuh, N. T. R., \& Seriang, A. (2020). Using HOTS-based chemistry national exam questions to map the analytical abilities of senior high school students. Journal of Science Learning, 3(3), 143148.

https://doi.org/10.17509/jsl.v3i3.22387

Hendrian, Rohaeti, \& Sumarmo. (2017). Hard skills and soft skills of student mathematics. Bandung: PT Refika Aditama.

Istuningsih, W., Baedhowi, B., \& Sangka, K. B. (2018). The effectiveness of scientific approach using e-module based on learning cycle 7E to improve students' learning outcome. International Journal of Educational Research Review, 3(3), 75-85.

https://doi.org/10.24331/ijere.449313

Kemendikbud. (2018). Peraturan menteri pendidikan dan kebudayaan republik Indonesia nomor 69 tahun 2013 tentang kerangka dasar dan struktur kurikulum sekolah menengah atas/madrasah aliyah. Retrieved from https://biologi.fkip.uns.ac.id/wpcontent/uploads/2013/08/PDK-2013\%0A69-Kerangka-Dasar-KurikulumKompetensi-SMA.pdf\%0A

Khoiriah, Jalmo, T., \& Abdurrahman. (2019). Effectiveness of assessment instruments higher order thinking skills to grow self regulated learning students junior high school. The Online Journal of New Horizons in Education, 9(2), 106-115. Retrieved from https://www.tojned.net/journals/tojned/ articles/v09i02/v09i02-03.pdf

Kusumawardani, R., Suhaiya, \& Muflihah. (2019). Difference in learning outcomes between high school student taught using learning cycle $5 \mathrm{E}$ and learning cycle 7E on colloid subject. $2^{\text {nd }}$ Educational Sciences International Conference (ES/C), 127-128. https://doi.org/10.2991/assehr.k.200417 .028
Maratusholihah, N. F., Rahayu, S., \& Fajaroh, F. (2017). Analisis miskonsepsi siswa sma pada materi hidrolisis garam dan larutan penyangga. Jurnal Pendidikan, 2(7), 919-926. https://doi.org/10.17977/jptpp.v2i7.964 5

Orgill, M., \& Sutherland, A. (2008). Undergraduate chemistry students' perceptions of and misconceptions about buffers and buffer problems. Chemistry Education Research and Practice, 9, 131-143. https://doi.org/10.1039/ b806229n

Othman, A., Talib, O., \& Ibrahim, D. A. (2015). Analisis dokumen silabus kimia organik matrikulasi berdasarkan taksonomi bloom. Jurnal Kurikulum \& Pengajaran Asia Pasifik, 3(3), 1-11. Retrieved from https://juku.um.edu.my/index.php/JUKU /article/view/8162/5645

Pallant, J. (2007). SPSS survival manual. Australia: Open University Press.

Paris, S. G., \& Paris, A. (2001). Classroom applications of research on self regulated learning. Educational Psychology, 36(2), 89-101. https://doi.org/10.1207/S15326985EP36 02_4

Sahin, A., Ayar, M. C., \& Adiguzel, T. (2014). STEM related after-school program activities and associated outcomes on student learning. Educational Sciences: Theory \& Practice, 14(1), 309-322. https://doi.org/10.12738/estp.2014.1.18 76

Salbiah, M. H., Ruhizan, M. Y., \& Rosalinda, R. (2015). A meta-analysis study on the effectiveness of higher order thinking skills (HOTS) based learning in science and mathematics subjects. Proceeding: $7^{\text {th }}$ International Seminar on Regional Education, 1334-1349. Retrieved from https://isre.prosiding.unri.ac.id/index.ph p/ISRE/article/view/3247/3159 
Sanaky, H. A. (2013). Media pembelajaran interaktif-inovatif. Yogyakarta: Kaukaba Dipantara.

Saraswati, S., Linda, R., \& Herdini. (2019). Development of interactive e-module chemistry magazine based on kvisoft flipbook maker for thermochemistry materials at second grade senior high school. Journal of Science Learning, 3(1), 1-6.

https://doi.org/10.17509/jsl.v3i1.18166

Sauki, N. I. M., \& Talib, O. (2020). SLR: The implementations of problem-solving method using polya, 5E, 7E method and its challenge to cope with $21^{\text {st }}$ century learning. International Journal of Academic Research in Business \& Social Sciences, 10(6), 1046-1060. https://doi.org/10.6007/IJARBSS/v10i6/7471

Sintema, E. J. (2020). Effect of covid-19 on the performance of grade 12 students: Implications for STEM education. EURASIA Journal of Mathematics, Science and Technology Education, 16(1). https://doi.org/10.29333/ejmste/

Smith, J. K. (2005). Reconsidering reliability in classroom assessment and grading. Educational Measurement: Issues and Practice, 22(4). https://doi.org/10.1111/j.17453992.2003.tb00141.x

Sornsakda, S., Suksringarm, P., \& Singseewo, A. (2009). Effects of learning environmental education using the 7Elearning cycle with metacognitive techniques and the teacher's handbook approaches on learning achievement, integreated science process skill and critical thinking of mathayomsuksa 5 students with different learning achievement. Pakistan Journal of Social Sciences, 6(5), 297-303. Retrieved from https://www.medwelljournals.com/abstr act/?doi=pjssci.2009.297.303
Tacoshi, M. M., \& Fernandez, C. (2014). Knowledge of assessment : an important component in the pck of chemistry teachers. Problems of Education in the 20th Century, 62, 124-147. Retrieved from http://oaji.net/articles/2015/4571423570850.pdf

UNESCO. (2009). World Conference on Higher Education: the New Dynamics of Higher Education and Research for Societal Change and Development; communiqué.

(https://unesdoc.unesco.org/ark:/48223 /pf0000183277), accessed 17 February 2021.

Voithofer, R. (2005). Designing new media education research: The materiality of data, representation, and dissemination. Educational Researcher, 34(9), 1-3. https://doi.org/10.3102/0013189X0340 09003

Warburton, K. (2003). Deep learning and education for sustainability. International Journal of Sustainability in Higher Education, 4(1), 44-56. https://doi.org/https://doi.org/10.1108/ 14676370310455332

Wickramasinghe, N. C., Steele, E. J., Gorczynski, R. M., Temple, R., Tokoro, G., Wallis, D. H., \& Klyce, B. (2020). Growing evidence against global infection-driven by person-to-person transfer of covid-19. Virol Curr Res, 4(1). Retrieved from https://www.theothersideofmidnight.co $\mathrm{m} / \mathrm{wp}-$ content/uploads/2020/04/Corona2.pdf

Wolters, C. A., Pintrich, P. R., \& Karabenick, S. A. (2009). Assessing academic selfregulated learning. The Search Institute Series on Developmentally Attentive Community and Society, 251-270. https://doi.org/10.1007/0-387-238239_16 
The Effectiveness of E-Module on Buffer Solutions to Improve Students' Higher-Order Thinking Skills and Self-Regulated Learning

Zimmerman, B. J. (1989). A Social Cognitive 25(1), 3-17. View of Self-regulated Learning. Journal of Educational Psychology, 81(3), 329$339 . \quad$ https://doi.org/10.1037/00220663.81.3.329

Zimmerman, B. J. (1990). Self-regulated learning and academic achievement: an overview. Educational Psychologist, https://doi.org/10.1207/s15326985ep25 01_2

Zumbrunn, S., Tadlock, J., \& Roberts, E. (2011). Encouraging self regulated learning in the classroom: a review of the literature. Virginia: Metropolitan Educational Research Consortium (MERC). 